\title{
Non-English Major Students' Perceptions toward the Teaching of English as a Compulsory Subject
}

\author{
Bahar $^{a^{*}}$, Dahlia Husain ${ }^{b}$ \\ ${ }^{a}$ Universitas Fajar, Makassar, Indonesia \\ ${ }^{b}$ Universitas Muhammadiyah Gorontalo, Gorontalo, Indonesia \\ *Corresponding Author: baharsetiawan@unifa.ac.id
}

\begin{abstract}
English as a compulsory subject in university means that students from various majors are mandated to take English as one of their subjects in university. This research aims to investigate student's perceptions toward the teaching of English as a compulsory subject at University. The evidence base has been conducted related to the subject, it seems salient to shed some light on this area, especially due to the importance of mastery of the English language these days. The result of the research showed that students have a good attitude toward the teaching of the English language as a compulsory subject. One of the most important discoveries lies with the students being motivated when the English being taught is closely related to their major. Due to some limitations of the study's suggestion for further research is expected.
\end{abstract}

Keywords: perception, teaching, compulsory subject

\section{INTRODUCTION}

The English language gained a first place as the most used foreign languages in most countries earned them this place. (Alptekin, 2002) the status of English as an intermediate language has become so popular that the language has become the key limitless field. English is the language of education, science, aviation, computers, diplomacy, and tourism. To be accepted and involved in such fields, mastery of the English language is very important. Knowing English elevated one's chances of securing better jobs, having a scholarship, and even working abroad. Mastering English means opportunities, higher education, and an even better life (Crystal, 1997). Moreover, (Chitravelu \& Sithamparan \& Choon, 2005, 4) claimed that English proficiency opens the door for bigger opportunities, especially in the education field, such as many Indonesian have been led by economic and social pressure to become a worker in some foreign countries for a better life. Their poor English skill, due to their lack of preparation before departure made it difficult for them to communicate well in the country of destination where they lived, and how Indonesian migrant workers have preparation their English skill in their country of origin Indonesia, and how they have acquired the language of the receiving country where they have worked, or how they maintained the foreign language which is acquired upon their return to Indonesia as their social capital. Most people who have good English skills have a better job.

In Indonesia, the English language has been mandated as one of the compulsory subjects at the university level. It means that all students at the university from every major are obliged to take an English subject. This has been implemented in all universities as an effort to prepare the students for the challenges in the future. At the university level, students faced with some expectation regarding English such as 1) students should be able to have their subjects presented in English, 2) read articles written in English on their subject, 3) express their 
Journal of Literature, Linguistics, and Language Teaching

Volume 2 (1) 2021

ISSN: 2746-8968 (online)

https://journal.unesa.ac.id/index.php/nld/index

opinion, both in spoken and in written form in English, etc. Based on my preliminary observation, the students at the university can barely do any of those things. Students find it very hard to understand classroom instruction when it is being presented in English because they lack English ability. That's why the ability to explore their knowledge by using English so difficult. Moreover, students are not enjoyable with articles in English when they need to let alone express themselves in English. Some of the problems the students faced are in terms of linguistic ability that includes grammar, use of the article, etc. (Brown, 2007) states that are also some factors that hinder the students to master the English language since learning another language is seen as a complex process with some variables. Therefore, it is important to consider students' perceptions in the teaching of English as a compulsory subject.

Campbell (1967) stated that perception is a result of a process of observing something or someone. When one observed something and has opinions about that exact matter, it means they perceived that thing. (Ajzen, 2005,3) argued that it was some sort of disposition to whether something or someone like it or not. This issue is relevant to the teaching of English as a compulsory subject. The reason for that is as a foreign language, English is not a daily used language so that is practicing the language is an issue that needs to be solved as well. Moreover, Singh, as cited in Basar, Sumardi, \& Zaini (2006) stated that the attitude toward English, in general, refers to the state of thoughts relating to the English language and the English-speaking community. Therefore, the issue of having an understanding of the students' perception of English language teaching at the university-level is salient. Similar research (Liu, 2007) investigated on Chinese student's motivation in learning English showed that the higher the students score in English the higher their motivation gets. The study also revealed otherwise, the students with the least score perceived English as dull and not enjoyable for them. Therefore, this particular research is aimed to find out students' perceptions toward the teaching of English as a compulsory subject at Fajar University in Makassar. In this case, the teacher is very involved to motivate the student in order student has the desire to learn English, which can be a provision for design to find work in the future (Honggang, 2008). This research is aimed to investigate the students' perception of the teaching of English as a compulsory subject.

\section{METHOD}

\section{STUDY DESIGN AND PARTICIPANT}

A cross-sectional descriptive study was conducted in August 2018 to analyze and evaluate the perception of the students among non-English majors. Participants were recruited from the Fajar University at Management Department. They mix with students remedial and new students. Purposive sampling was used with the inclusion criteria are participant's active students, have a student's ID, enrolled English subject, students are $1^{\text {st }}$ semester. Students who are not registered for the even semester period and do not completely answer the questionnaire were excluded from this study. There are twenty-seven students were participating in this, but only twenty students were completed filling the questionnaire.

\section{RESEARCH INSTRUMENT}

The perceptions of participating students in this study were evaluated using the perception of the student questionnaire in the Indonesian language, which is a validated scale. Which the questionnaire consists of several questions such as their filing about the importance of English class and their motives. Only 20 participating students completed the questionnaire. The 


\section{New Language Dimensions}

Journal of Literature, Linguistics, and Language Teaching

Volume 2 (1) 2021

ISSN: 2746-8968 (online)

https://journal.unesa.ac.id/index.php/nld/index

questionnaire consisted of 10 items based on a Likert scale ranging between 0 and $4(0=$ never, $1=$ seldom, $2=$ sometimes, $3=$ often and $4=$ always $)$.

\section{DATA COLLECTION PROCEDURE}

The researcher at Fajar University of Makassar, South Sulawesi, Indonesia collected the data. Invitation letters to join the study sent to the research and development of Fajar University of Makassar. Before the process, the data collection researcher invited participants and identified participants who meet the inclusion criteria. Researchers invited potential participants, by explaining the purpose of the study and procedures. Those who agreed to participate were asked to sign informed consent. Then, preliminary assessments were conducted to assess the perception of the student questionnaire.

\section{STATISTICAL ANALYSIS}

SPSS software version 20.0 (IBM SPSS, Chicago, IL, USA) was to apply statistical analysis. Descriptive statistics (frequency distribution) used to summarize the distributions of each variable, including each item of students' perception of teaching.

\section{FINDINGS AND DISCUSSION}

Use Times New Roman font 12 and single spacing for texts in a paragraph. Paragraphs are justified. No spacing between paragraphs. Next paragraphs indent (No spacing). This chapter includes method, setting and participants, techniques and instruments used, when applicable.

Students' perceptions toward the teaching of English as a compulsory subject are being examined through this research. The questionnaire was successfully administered to the students to gauge students' perceptions toward the teaching of English as a compulsory subject. The questionnaire consisted of 10 questions in which were projecting Students' perception toward the teaching of English as a compulsory subject. The findings revealed that;

Table 1. Students' perception towards the teaching of English as a compulsory subject.

\begin{tabular}{|c|c|c|c|c|c|c|c|}
\hline & Item number & Never & Seldom & Sometimes & Often & Always & Total \\
\hline \multirow[t]{2}{*}{1} & I dislike learning English as a & 10 & 7 & 3 & & & 20 \\
\hline & compulsory subject & $50 \%$ & $35 \%$ & $15 \%$ & & & $100 \%$ \\
\hline \multirow[t]{2}{*}{2} & I initiate learning English by & & 5 & 10 & 5 & & 20 \\
\hline & myself at home & & $25 \%$ & $50 \%$ & $25 \%$ & & $100 \%$ \\
\hline \multirow[t]{2}{*}{3} & I like it when the English teacher & 10 & 10 & & & & 20 \\
\hline & doesn't come to class & $50 \%$ & $50 \%$ & & & & $100 \%$ \\
\hline \multirow[t]{2}{*}{4} & I dislike the class when there is a & 5 & 15 & & & & 20 \\
\hline & homework check & $25 \%$ & $75 \%$ & & & & $100 \%$ \\
\hline \multirow[t]{2}{*}{5} & English is important for my future & & & 2 & 12 & 6 & 20 \\
\hline & & & & $10 \%$ & $60 \%$ & $30 \%$ & $100 \%$ \\
\hline \multirow[t]{2}{*}{6} & I worked on my assignments & & 2 & 13 & 5 & & 20 \\
\hline & wholeheartedly & & $10 \%$ & $65 \%$ & $25 \%$ & & $100 \%$ \\
\hline \multirow[t]{2}{*}{7} & I need we should have more & & 3 & 5 & 12 & & 20 \\
\hline & English classes & & $15 \%$ & $25 \%$ & $60 \%$ & & $100 \%$ \\
\hline \multirow[t]{2}{*}{8} & I am more motivated when the & & & 4 & 2 & 14 & 20 \\
\hline & subject is related to my field & & & $20 \%$ & $10 \%$ & $70 \%$ & $100 \%$ \\
\hline
\end{tabular}


Journal of Literature, Linguistics, and Language Teaching

Volume 2 (1) 2021

ISSN: 2746-8968 (online)

https://journal.unesa.ac.id/index.php/nld/index

\begin{tabular}{llcccc}
\hline 9 & The subject is interesting when & 7 & 12 & 1 & 20 \\
& it's combined with songs or & $35 \%$ & $60 \%$ & $5 \%$ & $100 \%$ \\
& videos & & & & \\
10 & 5 & 11 & 4 & 20 \\
I feel bored when I don't & $25 \%$ & $55 \%$ & $20 \%$ & $100 \%$ \\
\hline
\end{tabular}

Table 1 showed Students' perception toward the teaching of English as a compulsory subject. Item number one is I do not like English to become a compulsory subject. The table revealed that item number 1 there are 10 students $(50 \%)$ who think that they never dislike learning English as a compulsory subject, 7 students (35\%) seldom feels that dislike and the other 3 $(15 \%)$ that sometimes dislike their English as a compulsory subject. Regarding the items number 2, 5 students $(25 \%)$ percept that they initiate learning English by themselves at home. There are 10 students (50\%) that feel sometimes they should do it and the other 5 students (25\%) think they are often initiated learning English by themselves at home. In the items number 3, 10 students $(50 \%)$ percept that they never feel that they like it when the English teacher doesn't come to class. There are 10 students (50\%) that feels seldom like it when the English teacher doesn't come to class. In the items number 4, 5 students $(25 \%)$ think that they dislike the class when there is a homework check, and 15 students $(75 \%)$ percept that they seldom dislike the class when there is a homework check. In the items number 5, there are 2 students $(10 \%)$ that feel sometimes English is important for their future, the other 12 students $(60 \%)$ think they often think English is important for their future, and 6 students (30\%) always believe so. In the items number 6,2 students $(10 \%)$ percept that they seldom feel that way, 13 students $(65 \%) \%)$ feel sometimes they worked on their assignments wholeheartedly and the other 5 students $(25 \%)$ think they are often doing homework wholeheartedly. In the items number 7, 3 students (15\%) that feel seldom need they should have more English classes, the other 5 students $(25 \%)$ think they sometimes need that and 12 students $(60 \%) \%)$ that often think that they need more hours in their English subject. In the items number 8, 4 students $(20 \%)$ think they are sometimes motivated when the subject material is related to their subject, 2 students $(10 \%)$ are often motivated when the subject material is related to their subject, 14 students $(70 \%)$ they are always motivated when the subject material is related to their subject. In the items number 9, 7 students (35\%) think they sometimes think that the subject is interesting when it's combined with songs or videos, 12 students $(60 \%)$ often think that the subject is interesting when it's combined with songs or videos, 1 student (5\%) they always think that the subject is interesting when it's combined with songs or videos. In the items number 10, 5 students (25\%) seldom feel bored when they don't understand the subject material, the other 11 students $(55 \%)$ think they feel bored when they don't understand the subject material, and 4 students $(20 \%) \%)$ that often feel bored when they don't understand the subject material.

From the above findings, students seem to have a positive perception of English as a compulsory subject. It seems like English is recommended subject as (Ajzen 2005; p. 3) argued that it was some sort of disposition to whether something or someone is like or not like it. When asked about the importance of English, most students find it important for their future as claimed by (Sithamparan \& Choon 2005;p. 4) that English proficiency opens the door for bigger opportunities, especially in the education field.

Students also seem to project a positive attitude toward English which as Singh (cited in Basar, Sumardi \& Zaini, 2006,3) stated that the attitude toward English, in general, refers to a state of thoughts relating to the English language (Saracaloglu, 1992) the student's attitude toward learning a particular subject is deemed as an integral part of the learning, therefore, 


\section{New Language Dimensions}

Journal of Literature, Linguistics, and Language Teaching

Volume 2 (1) 2021

ISSN: 2746-8968 (online)

https://journal.unesa.ac.id/index.php/nld/index

should become an essential component of the learning pedagogy such as the lecturer said the rules or information that must be followed by students during the lecture, the lecturer can create conducive classroom atmosphere, lecturer check and return students assignment, lecturer explain the material to be taught and lecturer delivers the material easy way to understood by the students. Students are said they are motivated in learning English when the subject is closely related to their major meanwhile (Liu's, 2007) investigation on Chinese student's motivation in learning English showed that the higher the student's score in English the higher their motivation gets. The study also revealed otherwise, the students with the least score perceived English as dull and not enjoyable for them.

\section{CONCLUSION}

The finding of the study showed that students seem to have a positive perception of English as a compulsory subject. It seems like English is a recommended subject most students find it important for their future. The students also find that the more the subject related to their subject the more they are motivated to study English as a compulsory subject. It is advised the future research to include more variables into the research such as this.

\section{ACKNOWLEDGEMENT}

Many thanks to the Head of the Study Management Program who supported this research to be completed, also to my college Andi Febriana Thamrin.,SS., M.Hum., Ermansyah Malik, SS.M.Hum., Dahlia Husain, S.Pd,.M.Hum always helps me to any condition. This research was conducted by own expenses. Hopefully this article can contribute to the teaching English.

\section{REFERENCES}

Ajzen, I.(2005). The Influence of Attitudes on Behavior. (Eds) D. Albarracín, B. T. Johnson, M. P. Zanna. (2005). The handbook of attitudes. p. 173-221. Mahwah, NJ: Lawrence Erlbaum Associates.

Alptekin, C. (2002). Towards intercultural communicative competence. ELT Journal, 56(1), 57-64. https://doi.org/10.1093/elt/56.1.57

Basar, A., Sumardi, Naqiuddin, M., Hazriq, \& Zaini, A. (2006). The attitude of PISMP Students in IPBA toward English. Journal of Educational Research Seminar For Students IPBA.

Brown, H. D. (2007). Principles of Language Learning and Teaching. United States: Pearson Education. Inc

Campbell, D. T. (1967). Stereotypes and the perception of group differences. American Psychologist, 22, 817- 829. https://doi.org/10.1037/h0025079

Chitravelu, N., Sithamparan, S., \& Choon, T. S. (2005). ELT Methodology Principles and Practice. Shah Alam: Oxford Fajar.

Crystal, D. 1997. English as a Global Language. United Kingdom: Cambridge University Press. DOI: 10.1109/TPAMI.2002.1017623 


\section{New Language Dimensions}

Journal of Literature, Linguistics, and Language Teaching

Volume 2 (1) 2021

ISSN: 2746-8968 (online)

https://journal.unesa.ac.id/index.php/nld/index

Honggang, L. (2008). EFL motivations and autonomy in English learning: an investigation of Chinese non-English major undergraduates. CELEA journal. 31(5), 82-97. retrieved from: www.celea.org.cn.

Liu, M. (2007). Chinese students' motivation to learn English at the tertiary level. Asian EFL Journal, 9 (1), 126-146.

Ojala, T., Pietikainen, M. \& Maenpaa, T. (2002). Multiresolution gray-scale and rotation invariant texture classification with local binary patterns. IEEE Transactions on Pattern Analysis and Machine Intelligence. 24(7), 971-987.

Saracaloğlu A.S. (1992) The relation between students' attitudes toward foreign language and foreign language achievement. British council and Metu conferences. Ankara. 